процессе учета. Кроме того, данные изменения отражают требования и тенденции современной экономики.

$* * *$

1. Приказ Министерства финансов Российской Федерации от 22 мая 2020 года № 89н «Об утверждении программы разработки федеральных стандартов бухгалтерского учета государственных финансов на 2020-2023 гг." [Электронный источник] https://minjust.consultant.ru/documents/46674 (дата регистрации 23.06.2020г. рег. № 58750)

2. Приказ Минфина России от 30.06.2020 № 129н «Об утверждении федерального стандарта бухгалтерского учета государственных финансов «Финансовые инструменты». - [Электронный источник]/https://minfin.gov.ru/ru/document/?id_4=131543-

prikaz_minfina_rossii_ot_30.06.2020_129n_ob_utverzhdenii_federalnogo_standarta_bukhgalterskogo_ ucheta_gosudarstvennykh_finansov_finansovye_instrumenty/ (дата регистрации 23.09 .2020 г. рег. № 59996)

3. Приказ Минфина России от 15.11.2019 № 180н «Об утверждении Федерального стандарта бухгалтерского учета ФСБУ $5 / 2019$ «Запасы».- [Электронный источник]/https://minfin.gov.ru/ru/document/?id_4=129899-

prikaz_minfina_rossii_ot_15.11.2019_180n_ob_utverzhdenii_federalnogo_standarta_bukhgalterskogo_ ucheta_fsbu_52019_zapasy/ (дата регистрации 25.03.2020 рег. № 57837)

4. Приказ Минфина России от 05.06.2019 № 83н «Об утверждении программы разработки федеральных стандартов бухгалтерского учета на 2019 - 2021 гг. - [Электронный источник]/https://minfin.gov.ru/ru/document/index.php?id_4=127773 / (дата регистрации 27.06.2019 рег. № 55062)

5. Приказ Минфина России от 30.06.2020 №126н «Об утверждении федерального стандарта бухгалтерского учета государственных финансов «Отчетность по операциям системы казначейских платежей». -

https://minfin.gov.ru/ru/document/?id_4=130810-

prikaz_minfina_rossii_ot_30.06.2020_126n_ob_utverzhdenii_federalnogo_standarta_bukhgalterskogo_u cheta_gosudarstvennykh_finansov_otchetnost_po_operatsiyam_sistemy_kaznacheiski (дата регистрации 09.10.2020 рег. № 60328)

6. https://minfin.gov.ru/ru/

7. Какие нововведения ожидают бухгалтера бюджетной сферы в 2021 г. - [Электронный источник]/https://www.garant.ru/article/1430420/

8. Глобальные изменения в бухучете в 2021 году: новый учет активов и материалов. - [Электронный источник]/https://www.26-2.ru/art/355783-izmeneniya-v-buhgalterskom-uchete-v-2021-godu

\title{
Хаджимурадова T.X. \\ Проблемы выплаты пособия по временной нетрудоспособности в России: предложения по улучшению работы
}

ФГБОУ ВО Чеченский государственный университет (Россия, Грозньй)

doi: 10.18411/lj-04-2021-123

\section{Аннотация}

Утрата трудоспособности является серьезной проблемой для гражданина, так как она может повлиять на социальное положение семьи в целом. Исходя из этого, данный вопрос является особенно актуальным.

Ключевые слова: проблема, безработица, поддержка, помощь.

\section{Abstract}

Disability is a serious problem for a citizen, as it can affect the social status of the family as a whole. Based on this, this issue is particularly relevant.

Keywords: problem, unemployment, support, assistance.

В России страхование от несчастных случаев на производстве отсутствует. Его типичные функции обеспечиваются системой индивидуальной компенсации за потерю трудоспособности, которая представляет собой сложную схему страховых и 
нестраховых методов. Эта система обеспечивает только компенсацию материального ущерба и выплату пенсии по месту жительства жертве, но не оплачивает расходы, связанные с травмами на рабочем месте, а также на лечение профессиональных заболеваний или реабилитацию.

По оценкам экспертов, расходы, связанные с привилегиями и региональными пенсиями, а также расходы на индивидуальное возмещение в настоящее время составляют от 10 до 15\% фонда заработной платы в промышленности, а в некоторых регионах - от 15 до $35 \%$ и выше. В условиях экономической нестабильности проблема компенсации становится все более острой. Оплата жертвам либо задерживается, либо производится в уменьшенном размере, либо не выплачивается вообще [1, с.74].

Таким образом, предприятия, которые были преобразованы в акционерные общества, прекратили выплачивать компенсацию за потерю способности работать на своих бывших работников. Многие предприятия не возмещают эту компенсацию работникам, переехавшим из других стран СНГ. Реабилитация пострадавших от производства (40-50 тысяч человек в год) находится в крайне плачевном состоянии. Уровень медицинской, профессиональной и социальной реабилитации жертв крайне низок. В подавляющем большинстве таких случаев помощь не предоставляется. Это означает, что современная система индивидуальной компенсации, связанная с несчастными случаями на производстве, не отвечает изменениям, происходящим в настоящее время в российской экономике.

Страхование по безработице существует в Российской Федерации с 1991 года, хотя в российском законодательстве прямо не указано, что выплата пособий по безработице должна производиться Службой социального обеспечения. Общая схема выплаты пособий по безработице регулируется «Законом о занятости населения России». В соответствии с этим законом лица, потерявшие работу, имеют право на получение пособия по безработице на 12 месяцев (лица, не достигшие пенсионного возраста - на 24 месяца) в следующем порядке:

- общественный фонд компенсации за постоянную потерю трудоспособности;

- (оплата пропорциональна степени инвалидности и уровню заработной платы);

- компенсация за временную потерю трудоспособности;

- оплата медицинских справок в размере 100\% от заработной платы, компенсация за медицинское обслуживание в доме отдыха;

— компенсация за постоянную потерю трудоспособности;

- пенсии по инвалидности и компенсация за уход;

— пенсии по возмещению [2, с.36].

Российская модель компенсации за потерю трудоспособности из-за производственного травматизма в первые 3 месяца: 75\% месячной заработной платы за последнюю работу в последующие 4 месяца: $60 \%$ в последующем: 45\%, но не менее чем минимальная заработная плата и не более, чем средняя заработная плата в регионе.

Дополнительное пособие по социальному обеспечению - это выплата лицам, которые не имеют дохода. Описаны условия предоставления права на получение базового дополнительного пособия по социальному обеспечению, включая тест на средства.

Пособие по нетрудоспособности заменяется пособием по трудоустройству и поддержке. Если работник подает заявление на получение пособия по нетрудоспособности, будет проведена повторная оценка, чтобы определить, способен ли он работать или имеет право на получение пособии по нетрудоспособности.

Если инвалидность связана с работой, и поставщик услуг отказывает в выплаты пособий или прекращает выплаты пособий, работник может подать заявление. Для 
этого работник должен соответствовать всем требованиям закона о пособиях по временной нетрудоспособности, и подать официальную жалобу в Отдел компенсации работникам.

Пособие по нетрудоспособности обычно не затрагивается, если работник:

— выполняет волонтерскую работу;

— работает в среднем менее 16 часов в неделю и зарабатывать до 140 часов в неделю;

- работает и зарабатывать в неделю, если работа выполняется в рамках программы лечения или контролируется кем-то из местного совета или добровольной организации;

- работает и зарабатывать в неделю и освобожден от оценки личных способностей [3, с.86].

Для лиц, которые ищут работу впервые или пытаются возобновить свою трудовую деятельность после длительного периода отсутствия (более 1 года), а также для тех людей, которые потеряли работу и не имели оплачиваемой работы в течение 12 недель в течение за 12 месяцев, предшествующих периоду безработицы, уровень компенсации равен минимальной заработной плате.

Кроме того, лица, которые потеряли способность работать в результате производственного травматизма или профессионального заболевания, получают $100 \%$ средней заработной платы на последнем месте работы, но не больше, чем средняя заработная плата в регионе.

Выплаты по безработице финансируются Общественным фондом занятости Российской Федерации. Средства Фонда собираются из страховых взносов, уплачиваемых предприятиями, в размере $1,5 \%$ от общей суммы заработной платы. Настоящий метод, используемый для расчета уровня компенсации (основанный на средней заработной плате на последнем месте работы), является трудоемким и не подходит в условиях высокого уровня инфляции. В результате большинство безработных получают одинаковую компенсацию, которая зачастую ниже прожиточного минимума. Средний уровень компенсации по безработице составляет примерно $12 \%$ от средней заработной платы [4, с.16].

Действительная система социального страхования России не является страховкой в реальном смысле этого слова, потому что она по существу выполняет функцию социального обеспечения (пособие, помощь): размер страховых взносов не отражает уровень социального и профессионального региональный риск, а также степень прав и гарантий страхователя или страхователя. Как и прежде, как страхователи, так и застрахованные лишены возможности участвовать в управлении государственными средствами. Власти пытаются сохранить средства фондов социального страхования в федеральном бюджете под предлогом более эффективного использования.

Конечно, реформирование социального страхования, которое является очень важным институтом стабилизации общества, не является единичным случаем, проводимым в одночасье. Продолжается создание общей системы социального страхования в России, которая обеспечит приемлемый уровень социального обеспечения.

$$
* * *
$$

1. Смирнова Н.Л. Пособия по временной нетрудоспособности как вид страхового обеспечения по праву социального обеспечения современной России. Дис. канд. юр. Наук -Владивосток. 2002. $74 \mathrm{c}$.

2. Федин В.В. Юридический статус работника как субъекта трудового права. Монография. М.: Проспект, 2015. -36c.

3. Холостова Е.И. Социальная политика и социальная работа: учебное пособие / Е.И. Холостова. - 4е изд., перераб. и доп. - М.: Издательско-торговая корпорация «Дашков и К», 2013. - 86с.

4. Холостова Е.И. Пособия: Учебное пособие / Е.И. Холостова. - 3-е изд. перераб. и доп. - М.: Издательско-торговая корпорация «Дашков и Кํ», 2013. - 16 с. 